\title{
Effect of Organic and Inorganic Fertilization with Spraying of Fulvic Acid on Nutrients Uptake, Quality and Yield of Roselle (Hibiscus sabdariffa L.) Plant Grown in Sandy Soil at Siwa Oasis, Egypt
}

\author{
Moharam. F. Attia ${ }^{1}$
}

\begin{abstract}
During two successive seasons (2016 and 2017) at Khimisah experimental farm which is located at the latitude of $29^{\circ} 12^{\prime} 34.5 \mathrm{~N}^{\prime \prime}$, and the longitude of $25^{\circ} 24^{\prime}$ 2.56" E., Siwa Research Station, (Matrouh Governorate), Desert Research Center, Egypt, a field experiment was executed under irrigation with saline water $\left(4.2 \mathrm{dSm}^{-1}\right)$ to investigate the effect of five fertilizer combinations (FC) of both organic and inorganic fertilization as follows; $100 \%$ NPK recommended dose i.e. $180 \mathrm{kgN}, 31 \mathrm{kgP}$ and $100 \mathrm{kgK} \mathrm{ha}^{-1}$ (FC1), 50\% NPK+6MT compost ha-1 (FC2), $75 \% \mathrm{NPK}+$ 6MTha $^{-1}$ compost (FC3), 50\% NPK + 12MTcompost ha' h $^{-1}$ FC4) and 75\% NPK + 12 MTcompost $\mathrm{ha}^{-1}$ (FC5) and foliar application of fulvic acid at four levels i.e. $0.0,250,500$ and $750 \mathrm{mgL}^{-1}$ on the vegetative growth parameters, leaf nutrient uptake, yield and quality of roselle (Hibiscus sabdariffa L.) plants in arandomized complete block design with split plot technique in three replications where the main factor was five fertilizer combinations (FC) while the sub main factor was the foliar application of fulvic acid treatments (FA).
\end{abstract}

Results indicated that the single application of FC5 or FA (at $750 \mathrm{mgL}^{-1}$ ) showed the highest significant values for plant height $(\mathrm{cm})$, leaves number/plant, leaves dry weight g/plant, branches number/plant, branches fresh weight g/plant and branches dry weight /plant, leaf N, P, K, Fe, Zn and Mn uptake, sepals yield MTha ${ }^{-1}$, seed yield MTha ${ }^{-1}$, seed fixed oil yield $\mathbf{L h a}^{-1}$, sepals anthocyanin, vitamin C and acidity in both study seasons. The dual application of FC5 with FA at $750 \mathrm{mgL}^{-1}$ resulted in increasing in all studied parameters except sepals acidity which are reduced in both study seasons. It can be concluded that the dual application of FC5 with FA at $750 \mathrm{mgL}^{-1}$ is considered as a recommended treatment in the cultivation of roselle plants at Siwa Oasis due to it resulted in high yield and quality and the highest net profit $\left(40.450 \times 10^{3} \mathrm{ha}^{-1}\right)$ and the highest net return $\left(29.336 \times 10^{3} \mathrm{ha}^{-1}\right)$ and reducing theenvironmental pollution because of it had partial replacement of mineral fertilizer with organic one (compost and fulvic), especially under the conditions of Siwa Oasis as a natural reserve.

Keywords: Roselle, inorganic \& organic fertilization, leaf nutrients uptake, yield and quality.

\section{INTRODUCTION}

Roselle (Hibiscus sabdariffa, L.) is one of the most important plants of the Malvaceae Family, which produce a fleshly red calyxes and epicalyxes (sepals). Roselle sepals are used for the preparation of hot and cold red drinks and obtaining the natural food coloring pigments such as anthocyanin compounds (Diab, 1968). Moreover, it is used as hypotensive agent since it lowers blood pressure without producing side effect (Sharaf, 1962). In addition, Roselle seeds contain about 17-30\% fixed oil which is similar in its properties to cotton seed oil (Hussin et al., 1991). It has antimicrobial activities due to its phenolic compounds. It contains protein, fibers, calcium, iron, carotene, and ascorbic acid (Fasoyiro et al. 2005).

The NPK requirements of medicinal and aromatic plants were recorded by many authors. In this respect, Ashorabadi, et al. (2003) on Foeniculum vulgare, Niakan et al. (2004) on Mentha piperita, Lee et al. (2005) on Chrysanthemum boreale and Gomaa and Youssef (2007) on fennel plant, Amran (2013) on Pelargonium graveolens plants and El-Khyat (2013) on Rosmarinus officinalis. They concluded that NPK fertilizers had an important physiological and biochemical functions on structure of photosynthetic pigments, metabolism of carbohydrates and protein and these effects were observed with significant increase in growth, yield and essential oil content of the different plant species.

Organic fertilizers increase soil organic matter, particularly for the sandy soils in Egypt, which record less than $1 \%$ and hence improve the physical, chemical and biological properties. Consequently, the availability of nutrients for plants as well as soil characteristics should be improved (FAO, 1977). Compost application to sandy soil significantly increased both dry matter production of sepals and number of roselle plant fruits. It is used to increase anthocyanin and ascorbic acid contents in addition to a reduction of the acidity and glucose in sepals (Kandeel, 2004).

Balanced plant nutrition has an important role in increasing the quality and color of flowers. Hilbert et al. (2003) reported that high intake of potassium can increase the amount of anthocyanins, but it will be reduced by high amounts of nitrogen fertiliser. Research has shown that organic fertilizers or hormones can increase product quality and quantity. Shehata, et al

${ }^{1}$ Soil Fertility and Microbiology Dept., Desert research center, (Egypt)

Corresponding Author: E-mail: fouad_73@yahoo.com.

Received November 20, 2018, Accepted December 30, 2018 
(2011) reported that, by using compost the amounts of total soluble salt and anthocyanin levels in strawberry fruit have increased in greater extent with respect to chemical fertilizer. El-Shrief and Sarwat (2007) reported that the amount of anthocyanins, iron, zinc and manganese in Roselle flowers have increased by application of poultry manure.

Many beneficial effects are attributed to foliar application of fulvic acid (FA), including stimulation of plant metabolism, increased enzyme activity (transaminase, invertase), increased bioavailability and uptake of nutrients and increased crop growth and yield (Jifon and Lester, 2009). Fulvic acid has maximum influence on chemical reactions because of the presence of more electronegative oxygen atoms than any other humate molecules, which enhances membrane permeability (Priya et al., 2014). Application of fluvic acid positively affected plant growth under saline soil conditions, but higher doses of FA inhibited plant growth (Türkmen et al., 2004). Fluvic materials can affect physiological processes of plant growth directly or indirectly (Yang et al., 2013). Fluvic substances might show anti-stress effects under abiotic stress conditions such as, unfavorable temperature, $\mathrm{pH}$, salinity etc. Fluvic substances could improve plant growth under soil condition with enhancing the uptake of nutrients and reducing the uptake of some toxic elements (Kulikova et al., 2005). Fulvic acid easily binds or chelate minerals such as iron, calcium, copper, zinc and magnesium, as it can deliver this elements to plant directly (Yamauchi et al., 1984). Fulvic acid application enhanced root activity, increase in ion uptake, high rate of transport of phosphorus to the grains (Xudan, 1987), increasing the number and length of root hairs of Arabidopsis plants (Schmidt et al., 2005), promote plant growth and increase marketable yield in tomato production (Suh et al., 2014), improved plant growth and yield quantity and quality of cucumber plants and enhanced the activity of soil microorganism (Kamel et al., 2014), enhanced effectively the physiological activities and yield production of tomato plants, as antitranspirants via conserving soil water and thereby reduce the applied water by $25 \%$ of irrigation water (Aggag et al., 2015), improve the quality of berry fruit and more absorption of calcium by grape (Huanpu et al., 2004), enhanced potassium levels in leaves of tobacco acts in a manner similar to the plant hormone auxin (Priya et al., 2014).

Anjum et al. (2011) reported that fulvic acid increased chlorophyll and water content of leaves. It also increased photosynthesis, reduced stomata opening status and transpirations, thus led to growth stimulation and water loss reduction.
Aminifard et al. (2012) reported that fulvic acid enhanced multiple parameters of fruit quality, including total soluble solids, antioxidant activity, total phenolics, carbohydrates, capsaicin, and carotenoids of pepper. Bocanegra et al. (2006) concluded that "the combined capacity of fulvic acids both to chelate nutrients and move through membranes has suggested the fulvic acids may play similar roles as natural chelators in the mobilization and transport micronutrients". Moreover, Yang et al. (2013) have demonstrated that fulvic acid is optimum choice for the improvement of nutrients availability and soil physicochemical conditions. Anjum et al. (2011) reported that fulvic acid increased chlorophyll and water content of leaves. It also increased photosynthesis, reduced stomata opening status and transpirations, thus led to growth stimulation and water loss reduction (Li et al., 2005). Also they have found that fulvic acid and humic acid have been used to regulate the plant growth under well watered and drought conditions. Furthermore, fulvic acid as metabolic antitranspirations is an organic acid, nontoxic, not expensive and did not cause pollution problems as a result of extensive use (Nardi et al., 2002). Silva et al., (2016) observed that fulvic acid easily binds or chelate minerals such as iron, calcium, copper, zinc and magnesium, as it can deliver this elements to plant directly. Kamel et al. (2014) revealed that the foliar application of fulvic acid improved plant growth and yield quantity and quality of cucumber plants.

Li et al. (2005) indicated that falvic acid foliar spraying resulted to $7.2 \%$ increase of grain yield at the optimal concentration of fulvia acid $\left(1.5 \mathrm{mlL}^{-1}\right)$. Aggag et al. (2015) were studied the kaolin and fulvic acid as antitranspirants on tomato plants under three water regimes in the two seasons and revealed that both kaolin and fulvic acid enhanced effectively the physiological activities and yield production of tomato plants, These led to conserving soil water and thereby reduce the applied water by $25 \%$ of irrigation water. Anjum et al. (2011) reported that fulvic acid increased chlorophyll and water content of leaves. Fulvic acid also increased photosynthesis, reduced stomata opening status and transpiration, thus led to growth stimulation and water loss reduction. Zancani et al. (2011) suggested that fulvic acid applied to cell cultures of Greek fir interacted with the signaling pathway for plant hormones and increased intercellular levels of ATP and glucose-6phosphate, physiological effects that were related to growth promotion.

Yazdani et al. (2014) found higher nutrient uptake and accumulation of $\mathrm{N}, \mathrm{P}, \mathrm{K}, \mathrm{Ca}, \mathrm{Fe}$ and $\mathrm{Zn}$ in leaves of gerbera by fulvic acid. Hendawy et al. (2015) suggested that foliar application of humic acid had a significant 
effect on essential oil percentage and oil constituents of Mint plant. They concluded that increasing nutrient absorption can induce enzyme activity and metabolism of essential oil production. They also were stated that phosphorous can activate coenzymes for amino acid production, photosynthesis, glycolysis, respiration and fatty acid synthesis. On the other hands, increasing potassium absorption by fulvic acid may affect the metabolism of $\mathrm{N}$ and carbohydrates and the synthesis of lipid, starch and protein as reported by Zahra et al. (1984).

The cultivated area of roselle plant (Hibiscus sabdariffa L.) in Egypt is increasing gradually for local utilization and export. Using Egyptian desert soils in cultivating medical and aromatic plants such as roselle plant is considered as one of the most important targets especially in Siwa Oasis as a Protected Area where it is favourable to reduce application of chemical fertilizer and pesticides to prevent environmental pollution as possible. It is well known that most of irrigation water in Siwa Oasis is saline either agricultural drainage or well water. So this investigation aims to overcome these adverse conditions by cultivating economical and salinity tolerant plant such as roselle plant and trying to improve its leaf nutrients uptake, yield and quality by doing the integration between inorganic fertilizer and organic one such as compost and fulvic acid foliar spray.

\section{MATERIALS AND METHODS}

This study was performed at the Experimental Khamisa Farm (25 24' 2.56" E, $\left.29^{\circ} 12^{\prime} 34.5^{\prime \prime} \mathrm{N}\right)$, Siwa Research Station, Desert Research Center during 2016 and 2017 seasons to study the effect of five fertilizer combinations (FC) of both organic and inorganic fertilization as follows; $100 \%$ NPK of recommended dose (FC1) i.e. $180 \mathrm{kgN}, 31 \mathrm{kgP}$ and $100 \mathrm{kgKha}^{-1}$ in the form of ammonium sulfate, superphosphate and potassium sulfate, respectively), $50 \% \mathrm{NPK}+6 \mathrm{MT}$ compostha $^{-1}$ (FC2), 75\%NPK+ 6MT compostha ${ }^{-1}$ (FC3), $50 \% \mathrm{NPK}+12 \mathrm{MTcompostha}^{-1}$ (FC4) and 75\%NPK + 12MTcompostha ${ }^{-1}$ (FC5) with foliar application of fulvic acid (FA) at four levels i.e. 0.0, 250, 500 and $750 \mathrm{mgL}^{-1}$ on vegetative growth, leaf nutrient uptake, yield and quality of roselle (Hibiscus sabdariffa L.) plants. This experiment was conducted in a split plot design with three replicates where the five combinations of both organic and inorganic fertilizers were assigned in the main plot, while the foliar application treatments of fulvic acid were assigned in the sub main plot.

Some physical and chemical properties of the experimental soil were determined according to Jackson (1973) and Black et al. (1982). The obtained results of soil analyses are presented in Table 1 . The chemical properties of applied compost, which are producing from plant wastes and animal manure, and irrigation water, are also shown in Table 1.

Roselle seeds were sown in sandy soil on 15 March of each season in plots $(1.5 \times 6 \mathrm{~m})$ containing three rows $(50 \mathrm{~cm}$ width) every row had 12 hills $(50 \mathrm{~cm}$ apart) and at three seeds per hill, and one month later, the plants were thinned, leaving only one seedling/hill.

The amount of $\mathrm{N}$ and $\mathrm{K}$ fertilizers were divided into three equal portions as side dressing and added at three dates: on 15 June, on 15 July and on 15 August, respectively of both study seasons. However, the amount of P-fertilizer and compost were added to the soil before seed sowing during soil preparation. Fulvic acid treatments were applied as foliar spray at 30, 60 and 90 days after planting, respectively.

Table 1. Some physical and chemical properties of the experimental soil, applied compost and irrigation water at Khamisa farm

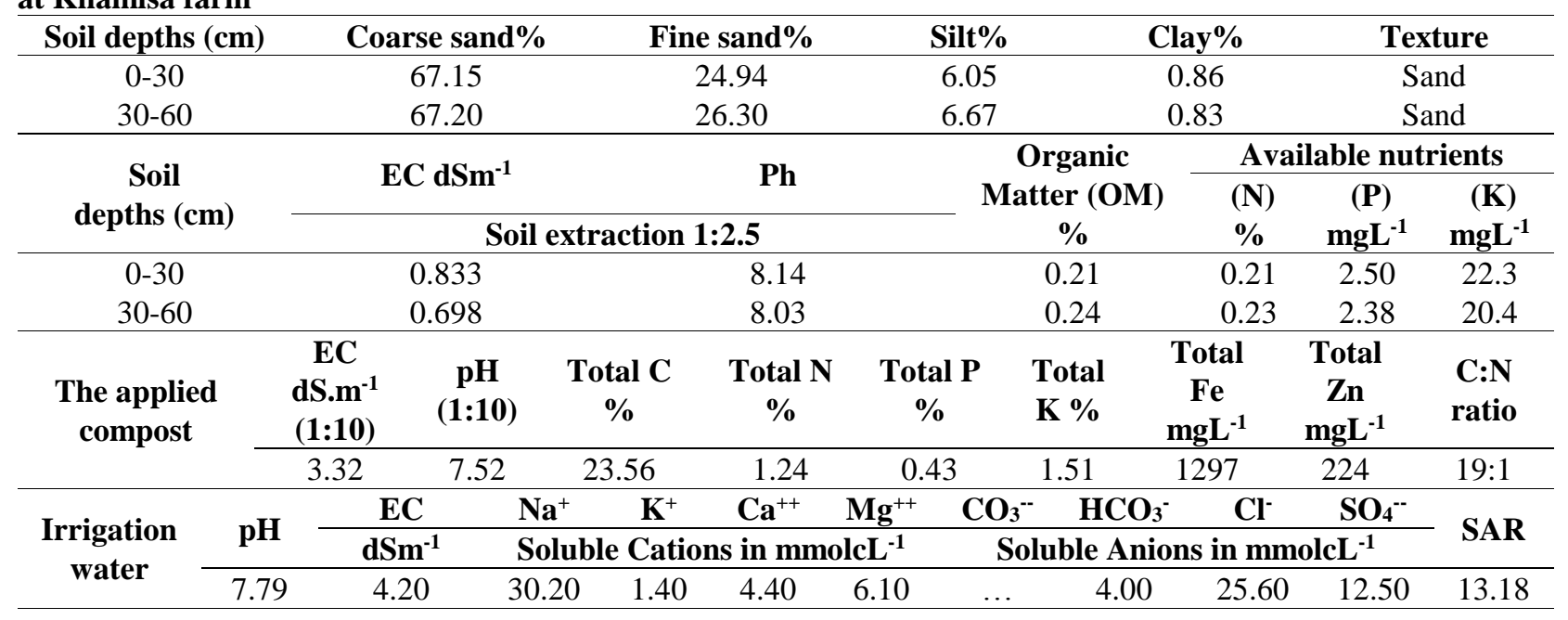


Vegetative growth parameters such as plant height (cm.), number and dry weight of leaves (g)/plant, number, fresh and dry weight of branches $(\mathrm{g}) /$ plant were taken at the beginning of flowering stage; on 30 August, 2016 and 2017 seasons.

Data of yield parameters as sepals yield $\left(\mathrm{MTha}^{-1}\right)$, seed yield in $\left(\right.$ MTha $\left.^{-1}\right)$ and seed fixed oil yield $\left(\mathrm{MTha}^{-1}\right)$ were recorded at harvesting time i.e. 15 October, 2016 and 2017 seasons (i.e. growth season duration was about 7 months).

The determinations of chemical constituents were determined as follows; at harvesting time (on 15 October) anthocyanin content was determined in airdried roselle sepals according to the method described by Du and Francis (1973), the percentage of fixed oil in seeds was determined according to the method mentioned by A.O.A.C (1980), ascorbic acid was determined in sepals as described in A.O.A.C. (1980), sepals acidity ( $\mathrm{pH}$ value) was determined according to Diab (1968), while during flowering stage (on 30 August), the percentage of $\mathrm{N}, \mathrm{P}, \mathrm{K}$ and total carbohydrates\% were determined in the dry leaves, where total nitrogen was determined using MicroKieldahl method according to A.O.A.C. (1980), phosphorus was determined colourimetrically in spectrophotometer using the method described by Trouge and Meyer (1939), whereas, K content was determined by flame photometer according to Brown and Lilleland (1946), Fe, Zn, and Mn were determined in the wet digested samples by atomic absorption as described by Chapman and Paratt (1961). Total carbohydrates (mg/g D.W), total sugars (mg/g F.W), total free amino acids (mg/g F.W), chlorophyll a \& b and carotenoids (mg/g F.W), were determined in the roselle leaves at the beginning of flowering stage according to Herbert et al. 1971, Thomas and Dutcher, 1924, Rosed,1957 and A.O.A.C, 1980, respectively.

All data obtained in both seasons of study were subjected to statistical analysis of variance as factorial experiments in split plot design. L.S.D. method was used to differentiate means according to Snedecor and Cochran (1989).

\section{RESULTS AND DISCUSSION}

The highest plant height (147.1 and $151.4 \mathrm{~cm})$, branches fresh weight (1125.5 and 1216.1g/plant) and branches dry weight (201.4 and 208.6g/plant) were recorded with the treatment of the full dose of mineral fertilizers (FC1), the second highest plant (143.4 and $174.5 \mathrm{~cm}$ ) was noticed at $\mathrm{FC} 3$ treatment whereas no significant differences were observed between FC1, FC3 and FC5 regarding their effect on both fresh and dry weight of branches, combination of inorganic and organic fertilizers at $75 \%+12 \mathrm{MT}$ compostha ${ }^{-1}$ (FC5) achieved the highest leaves number (140.1 and 147.5), branches number (20.95 and 22.11) and leaves dry weight (24.23 and 26.37), there were no significant differences were noticed among the effects of FC1, FC3 and FC5 concerning their effect on leaves number in the $1^{\text {st }}$ and $2^{\text {nd }}$ seasons, respectively. On the other hand application of $50 \%$ inorganic fertilizers $+6 \mathrm{MT}$ compostha $^{-1}$ (FC2) scored the lowest values of all studied vegetative growth parameters in both study seasons.

With respect to the effect of foliar application of fulvic acid levels, Tables 2 and 3 reveal that most of all the studied vegetative growth parameters were gradually increased with increasing of fulvic acid (FA) concentrations over the control with superiority of $750 \mathrm{mg} / \mathrm{L}$ level, there were significant differences between all FA levels regarding their effect on plant height, leaves number and branches fresh weight. No significant differences between 500 and $750 \mathrm{mg} / \mathrm{L}$ of FA levels concerning their effect on leaves dry weight, branches dry weight and branches number in the two study seasons.

As shown in Tables 2 and 3, the interaction effect between the inorganic and organic fertilizer combinations (FC) and the levels of fulvic acid (FA) increased all the studied vegetative growth parameters of Roselle plant in both seasons. However, the highest significant interaction treatment was the foliar application of FA at $750 \mathrm{mg} / \mathrm{L}$ with FC5 $(70 \%$ mineral + 5.0MT compost $\mathrm{ha}^{-1}$ ) regarding leaves number (146.0 and 156.1), leaves dry weight (27.08 and $29.72 \mathrm{~g} /$ plant) and branches number (23.97 and 25.19) and with FC1 $(100 \%$ mineral) concerning plant height (153.2 and $156.1 \mathrm{~cm})$, branches fresh weight $(1190.9$ and $1365.1 \mathrm{~g} / \mathrm{plant})$ and branches dry weight (209.4 and $232.9 \mathrm{~g} /$ plant) in the $1^{\text {st }}$ and $2^{\text {nd }}$ seasons, respectively.

These results are in accordance with those obtained by El-khayat (2001) on roselle plants, Niakan et al. (2004) on Mentha piperita, El-Maadawy and Moursy (2007) on jojoba, El-Shora (2009) on Mentha piperita, Khalil et al. (2010) on basil plants, Majeed and Ali (2011) on roselle plant, Gendy et al. (2012) on roselle plants, Gendy et al. (2013) on guar plants, Priya et al. (2014) on tobacco plant, Paramasivan et al. (2015) on Solanum melongena L., Khatab (2016) on roselle plant and Moradi et al (2017) on safflower plant. 
Table 2.Effect of fulvic acid (FA) and Fertilizer combinations (FC) on plant height (cm), leaves number and leaves dry weights of roselle plants during 2016 and 2017 seasons

\begin{tabular}{|c|c|c|c|c|c|c|c|c|c|c|c|c|c|c|c|}
\hline \multicolumn{16}{|c|}{ First Season (2016) } \\
\hline \multirow{3}{*}{$\begin{array}{c}\text { Parameters } \\
\text { FC } \\
\text { treatments* }\end{array}$} & \multirow{2}{*}{\multicolumn{4}{|c|}{$\begin{array}{c}\text { Plant height }(\mathrm{cm}) \\
\text { Fulvic Acid (FA) in moL }{ }^{-1}\end{array}$}} & \multirow{3}{*}{ Mean } & \multirow{2}{*}{\multicolumn{4}{|c|}{$\begin{array}{l}\text { Leaves number/plant } \\
\text { Fulvic Acid (FA) in } \text { mgL }^{-1}\end{array}$}} & \multirow{3}{*}{ Mean } & \multirow{2}{*}{\multicolumn{4}{|c|}{$\begin{array}{l}\text { Leaves dry weight g/plant } \\
\text { Fulvic Acid (FA) in } \text { mgL }^{-1}\end{array}$}} & \multirow{3}{*}{ Mean } \\
\hline & & & & & & & & & & & & & & & \\
\hline & $\mathbf{0}$ & 250 & 500 & 750 & & $\mathbf{0}$ & 250 & 500 & 750 & & $\mathbf{0}$ & 250 & 500 & 750 & \\
\hline FC1 & 139.2 & 146.2 & 149.9 & 153.2 & 147.1 & 134.6 & 140.3 & 139.6 & 145.9 & 140.1 & 21.45 & 23.53 & 22.90 & 25.61 & 23.37 \\
\hline FC2 & 131.7 & 134.9 & 135.7 & 138.0 & 135.1 & 100.8 & 103.3 & 109.8 & 105.7 & 104.9 & 15.35 & 17.72 & 17.12 & 20.09 & 17.57 \\
\hline FC3 & 137.5 & 142.8 & 145.1 & 148.1 & 143.4 & 134.2 & 140.1 & 140.3 & 145.9 & 140.1 & 21.26 & 23.80 & 23.79 & 26.35 & 23.80 \\
\hline FC4 & 132.9 & 136.2 & 137.4 & 139.5 & 136.5 & 110.3 & 115.3 & 124.6 & 120.4 & 117.7 & 17.54 & 20.35 & 22.28 & 23.17 & 20.83 \\
\hline FC5 & 135.7 & 139.4 & 140.3 & 143.1 & 139.6 & 133.7 & 139.9 & 140.9 & 146.0 & 140.1 & 21.08 & 24.08 & 24.68 & 27.08 & 24.23 \\
\hline Mean & 135.4 & 139.9 & 141.7 & 144.4 & & 122.7 & 127.8 & 131.0 & 132.8 & & 19.33 & 21.90 & 22.15 & 24.46 & \\
\hline LSD0.05 & \multicolumn{5}{|c|}{$\mathrm{FC}=1.0208 \mathrm{FA}=0.913 \mathrm{FC} \times \mathrm{FA}=0.189$} & \multicolumn{3}{|c|}{$\mathrm{FC}=1.758 \mathrm{FA}=1.572$} & \multicolumn{2}{|c|}{$\mathrm{FC} \times \mathrm{FA}=0.518$} & \multicolumn{5}{|c|}{$\mathrm{FC}=0.424 \quad \mathrm{FA}=0.380 \quad \mathrm{FC} \times \mathrm{FA}=0.104$} \\
\hline \multicolumn{16}{|c|}{ Second Season (2017) } \\
\hline FC1 & 146.0 & 151.1 & 152.3 & 156.1 & 151.4 & 139.7 & 144.4 & 146.9 & 149.1 & 145.0 & 21.30 & 24.06 & 24.49 & 27.68 & 24.38 \\
\hline FC2 & 134.6 & 138.4 & 139.7 & 142.2 & 138.8 & 99.4 & 118.2 & 103.4 & 137.0 & 114.5 & 15.41 & 18.64 & 20.52 & 25.64 & 20.05 \\
\hline FC3 & 142.8 & 147.3 & 148.3 & 151.8 & 147.5 & 138.5 & 145.5 & 149.2 & 152.6 & 146.5 & 21.91 & 25.59 & 25.30 & 28.70 & 25.38 \\
\hline FC4 & 137.5 & 140.7 & 140.7 & 143.8 & 140.7 & 112.9 & 123.8 & 131.9 & 134.7 & 125.8 & 19.43 & 22.81 & 22.41 & 25.38 & 22.51 \\
\hline FC5 & 139.7 & 143.5 & 144.2 & 147.4 & 143.7 & 137.3 & 146.7 & 151.6 & 156.1 & 147.9 & 22.53 & 27.13 & 26.12 & 29.72 & 26.37 \\
\hline Mean & 140.1 & 144.2 & 145.1 & 148.3 & & 125.5 & 135.7 & 136.6 & 145.9 & & 20.12 & 23.65 & 23.77 & 27.42 & \\
\hline LSD0.05 & \multicolumn{2}{|c|}{$\mathrm{FC}=0.459 \mathrm{~F}$} & $=0.410$ & $\mathrm{FC} \times \mathrm{FA}=$ & .189 & \multicolumn{3}{|c|}{$\mathrm{FC}=4.38 \quad \mathrm{FA}=3.92$} & $\mathrm{C} \times \mathrm{FA}=$ & 542 & \multicolumn{2}{|c|}{$\mathrm{FC}=0.620 \quad \mathrm{~F}$} & $=0.554$ & \multicolumn{2}{|c|}{$\mathrm{FC} \times \mathrm{FA}=0.118$} \\
\hline
\end{tabular}

*FC1; Mineral 100\% (180N as ammonium sulphate, 31P as ordinary super phosphate \& 10K as potassium sulphate kgha $\left.{ }^{-1}\right) \quad \mathrm{FC}^{2} ; \mathrm{Mineral}^{50 \%}+6 \mathrm{MT}$ compostha ${ }^{-1}$, FC3; Mineral $75 \%+6 \mathrm{M} \mathrm{T}$ compostha ${ }^{-1}$, FC4; Mineral 50\% + 12MT compostha ${ }^{-1}$, FC5; Mineral 75\%+ 12MT compostha ${ }^{-1}$. 
Table 3.Effect of fulvic acid (FA) and Fertilizer combinations (FC) on number, fresh weight (F.W.) and dry weight (D.W.) of branches of roselle plants during 2016 and 2017 seasons

First Season (2016)

\begin{tabular}{|c|c|c|c|c|c|c|c|c|c|c|c|c|c|c|c|}
\hline $\begin{array}{c}\text { Parameters } \\
\text { FC } \\
\text { treatments* }\end{array}$ & \multicolumn{4}{|c|}{$\begin{array}{l}\text { Branches number/plant } \\
\text { Fulvic Acid (FA) in } \text { mgL }^{-1}\end{array}$} & Mean & \multicolumn{4}{|c|}{$\begin{array}{l}\text { Branches fresh weight g/plant } \\
\text { Fulvic Acid (FA) in } \mathrm{mgL}^{-1}\end{array}$} & Mean & \multicolumn{4}{|c|}{$\begin{array}{l}\text { Branches dry weight /plant } \\
\text { Fulvic Acid (FA) in } \text { mgL }^{-1}\end{array}$} & Mean \\
\hline FC1 & 17.12 & 19.24 & 22.87 & 19.99 & 19.80 & 1033.6 & 1112.2 & 1165.4 & 1190.9 & 1125.5 & 190.2 & 199.8 & 206.4 & 209.4 & 201.4 \\
\hline FC2 & 14.96 & 16.26 & 17.20 & 16.08 & 16.12 & 782.9 & 845.8 & 799.0 & 908.7 & 8 & 3 & .9 & .3 & 16 & 150.2 \\
\hline FC4 & 16.25 & 18.07 & 19.66 & 17.96 & 17.98 & 820.3 & 923.5 & 941.8 & 1026.8 & 928.1 & 148.4 & 167.4 & 171.3 & 186.3 & 168.3 \\
\hline FC5 & 18.05 & 20.77 & 23.97 & 21.01 & 20.95 & 1047.2 & 1107.1 & 1145.8 & 1167.1 & 1116.8 & 192.7 & 199.9 & 204.8 & 207.1 & 201.1 \\
\hline Mean & 16.79 & 18.87 & 21.42 & 19.11 & & 944.9 & 1019.7 & 1041.5 & 1094.5 & & 172.4 & 183.7 & 186.7 & 195.1 & \\
\hline FC1 & 18.48 & 21.04 & 21.42 & 23.60 & 21.13 & 1059.1 & 1228.3 & 1212.1 & 1365.1 & 1216.1 & 182.2 & 212.0 & 207.5 & 232.9 & 208.6 \\
\hline FC2 & 15.95 & 17.08 & 20.66 & 18.22 & 17.97 & 847.5 & 856.8 & 974.5 & 1101.6 & 945.1 & 145.7 & 143.4 & 169.1 & 192.4 & 162.6 \\
\hline FC3 & 18.65 & 21.52 & 21.91 & 24.39 & 21.62 & 1075.3 & 1205.3 & 1193.0 & 1310.7 & 1196.1 & 187.6 & 210.8 & 207.0 & 226.4 & 208.0 \\
\hline FC4 & 16.86 & 19.13 & 19.66 & 21.39 & 19.26 & 865.3 & 998.8 & 960.5 & 1055.7 & 970.1 & 154.0 & 175.4 & 169.8 & 185.6 & 171.2 \\
\hline FC5 & 18.83 & 22.01 & 22.41 & 25.19 & 22.11 & 1091.4 & 1182.4 & 1173.9 & 1256.3 & 1176.0 & 193.0 & 209.6 & 206.5 & 220.0 & 207.3 \\
\hline Mean & 17.75 & 20.15 & 21.21 & 22.55 & & 987.7 & 1094.3 & 1102.8 & 1217.9 & & 172.5 & 190.2 & 192.0 & 211.5 & \\
\hline
\end{tabular}

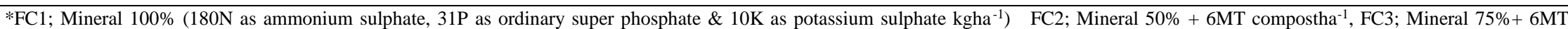
compostha $^{-1}$, FC4; Mineral 50\% + 12MT compostha ${ }^{-1}$, FC5; Mineral 75\%+ 12MT compostha ${ }^{-1}$. 


\section{Leaf nutrients uptake:}

\subsection{Leaf macronutrients uptake:}

As presented in Table 4, although FC1 gave the highest roselle leaf macronutrients uptake (16.80 and $18.19,3.739$ and 3.722 , and 29.28 and $29.74 \mathrm{kgha}^{-1}$ ) for $\mathrm{N}, \mathrm{P}$ and $\mathrm{K}$ in the $1^{\text {st }}$ and $2^{\text {nd }}$ season, respectively, there were no significant differences between FC1, FC3 and FC5 (Table, 4).

The highest significant FA foliar application treatment was FA4 which achieved the highest roselle leaf macronutrients uptake (17.47 and 19.70, 3.758 and 4.020, and 29.38 and $32.04 \mathrm{kgha}^{-1}$ ) for $\mathrm{N}, \mathrm{P}$ and $\mathrm{K}$ in the $1^{\text {st }}$ and $2^{\text {nd }}$ season, respectively.

Concerning the interaction effect of FC with FA treatments data in Table 4 reveal that the highest values for $\mathrm{N}, \mathrm{P}$ and $\mathrm{K}$ uptake by roselle plant leaves were due to the interactions of FC1, FC3 and FC5 with FA at $750 \mathrm{mgL}^{-1}$, respectively and there were no significant differences among all those three interaction treatments in both study seasons.

\subsection{Leaf micronutrients uptake:}

Table 5 indicated that there are significant differences among all fertilizer combinations (FC) treatments regarding $\mathrm{Fe}$ and $\mathrm{Mn}$ uptake of leaf roselle plant while no significant differences among FC1, FC3 and FC5 were observed for $\mathrm{Zn}$ uptake. The highest values were achieved by FC5 for Fe and Mn uptake and by FC1 for Zn uptake. On contrary the lowest significant treatment was FC2.

Foliar application of fulvic acid (FA) at $750 \mathrm{mgL}^{-1}$ was the highest significant treatment which gave the highest leaf micronutrients uptake values i.e. 847.9 and 937.7gha ${ }^{-1}$ for $\mathrm{Fe}, 439.4$ and 523.4.gha ${ }^{-1}$ for $\mathrm{Zn}$ and 214.4 and $218.5 \mathrm{gha}^{-1}$ for $\mathrm{Mn}$ in the $1^{\text {st }}$ and $2^{\text {nd }}$ seasons, respectively, while the lowest significant treatment was observed at without FA foliar application treatment in both study seasons (Table, 5).

With respect to the interaction between FC and FA treatments (Table, 5), the highest significant interaction treatment was the foliar application of FA at $750 \mathrm{mgL}^{-1}$ with FC5 (70\% mineral + 12MT compostha $\left.{ }^{-1}\right)$ for both $\mathrm{Fe}$ (971.8 and 1042.6gha ${ }^{-1}$ ) and $\mathrm{Mn}$ (251.5 and 262.2 $\mathrm{gha}^{-1}$ ) and with FC1 for Zn (505.9 and 580.1 gha $^{-1}$ ) in the $1^{\text {st }}$ and $2^{\text {nd }}$ seasons, respectively.

The previous results of fertilization regarding leaf nutrients uptake are in agreement with those obtained by El-khayat (2001) on roselle plants, Niakan et al. (2004) on Mentha piperita, El-Maadawy and Moursy (2007) on jojoba, El-Shora (2009) on Mentha piperita, Khalil et al. (2010) on basil plants, Majeed and Ali (2011) on roselle plant, Gendy et al. (2012) on roselle plants,
Gendy et al. (2013) on guar plants, Priya et a.l (2014) on tobacco plant, Paramasivan et al. (2015) on Solanum melongena L., Khatab (2016) on roselle plant and Moradi et al (2017) on safflower plant.

\section{Yields of roselle plant:}

\subsection{Dry sepals yield:}

It is clear from data in Table 6 that there are significant differences between all inorganic and organic fertilizers combinations (FC) regarding their effect on dry sepals yield in MT ha- ${ }^{-1}$. The highest dry sepals yield (1.075 and 1.217 $\mathrm{MTha}^{-1}$ ) was achieved at FC5 followed by FC3 treatments, whereas, the lowest dry sepals yield $\left(0.840\right.$ and0.965 $\left.\mathrm{MTha}^{-1}\right)$ was noticed at $\mathrm{FC} 2$ treatment in the $1^{\text {st }}$ and $2^{\text {nd }}$ seasons, respectively.

Data in Table 6 indicate that all levels of fulvic acid (FA) resulted in significant increases in dry sepals yield especially that received the high level $\left(750 \mathrm{mgL}^{-1}\right)$ as compared with no FA application in the two study seasons. In general, all resulted interactions between FC and FA treatments statistically affected the sepals dry yield $\left(\mathrm{MTha}^{-1}\right)$ in both seasons. However, the highest sepals dry yield (1.212 and 1.294MTha $\left.{ }^{-1}\right)$ was earned by using the combined treatments between FC5 and FA at $750 \mathrm{mgL}^{-1}$ when compared with other combinations in the $1^{\text {st }}$ and $2^{\text {nd }}$ seasons, respectively.

\subsection{Seed yield:}

Although, FC1 treatment gave the highest seed yield (1.622 and $\left.1.745 \mathrm{MTha}^{-1}\right)$, it didn't significantly differ with FC3 and FC5 (Table, 6), whereas the lowest seed yield (1.315 and 1.452 $\left.\mathrm{MTha}^{-1}\right)$ was observed at FC2 treatment in the $1^{\text {st }}$ and $2^{\text {nd }}$ season, respectively. Foliar application of FA at $750 \mathrm{mgL}^{-1}$ gave the highest significant seed yield (1.750 and $\left.1.726 \mathrm{MTha}^{-1}\right)$ and the lowest one (1.325 and $\left.1.548 \mathrm{MTha}^{-1}\right)$ was observed at no FA foliar application in the $1^{\text {st }}$ and $2^{\text {nd }}$ season, respectively. The interaction treatments between FC and FA treatments affected significantly on seed yield where the highest seed yield was gained at $\mathrm{FC} 1$ with $\mathrm{FA}$ at $750 \mathrm{mgL}^{-1}$ treatment followed by FC3 with FA at $750 \mathrm{mgL}^{-1}$ and FC5 with FA at $750 \mathrm{mgL}^{-1}$ in both study seasons.

\subsection{Seed fixed oil yield:}

As presented in Table 6, significant differences were observed between all organic and inorganic fertilizer combinations (FC). FC5 had the highest seed fixed oil yield (236.9 and 260.01 $\mathrm{Lha}^{-1}$ ) followed by FC3 and FC1, whereas FC2 treatment gave the lowest seed fixed oil yield in the $1^{\text {st }}$ and $2^{\text {nd }}$ season, respectively. Foliar application of FA on roselle plant significantly increased seed fixed oil yield per ha, especially with high level (750 $\left.\mathrm{mgL}^{-1}\right)$ in both study seasons. The interaction treatment of FC5 with FA at $750 \mathrm{mgL}^{-1}$ gave the highes. 
Table 4.Effect of fulvic acid (FA) and Fertilizer combinations (FC) on N, P and K uptake of leaves of of roselle plants during 2016 and 2017 seasons

\begin{tabular}{|c|c|c|c|c|c|c|c|c|c|c|c|c|c|c|c|}
\hline \multicolumn{16}{|c|}{ First Season (2016) } \\
\hline \multirow{2}{*}{$\begin{array}{c}\text { Parameters } \\
\begin{array}{c}\text { FC } \\
\text { treatments* }\end{array}\end{array}$} & \multicolumn{4}{|c|}{$\begin{array}{c}\text { N uptake }\left(\mathrm{kgha}^{-1}\right) \\
\text { Fulvic Acid }(\mathrm{FA}) \text { in } \mathrm{mgL}^{-1}\end{array}$} & \multirow[t]{2}{*}{ Mean } & \multicolumn{4}{|c|}{ Fulvic Acid (FA) in $\mathrm{mgL}^{-1}$} & \multirow[t]{2}{*}{ Mean } & \multicolumn{4}{|c|}{ Fulvic Acid (FA) in $\mathrm{mgL}^{-1}$} & \multirow[t]{2}{*}{ Mean } \\
\hline & $\mathbf{0}$ & 250 & 500 & 750 & & $\mathbf{0}$ & 250 & 500 & 750 & & $\mathbf{0}$ & 250 & 500 & 750 & \\
\hline FC1 & 14.62 & 15.98 & 17.06 & 19.51 & 16.80 & 2.959 & 3.816 & 3.713 & 4.469 & 3.739 & 25.42 & 29.09 & 29.90 & 32.74 & 29.28 \\
\hline FC3 & 13.51 & 16.80 & 16.68 & 19.87 & 16.73 & 2.674 & 3.223 & 3.449 & 4.224 & 3.391 & 23.18 & 28.42 & 28.15 & 33.65 & 28.34 \\
\hline FC4 & 10.90 & 14.21 & 13.06 & 15.22 & 13.34 & 2.244 & 2.856 & 2.724 & 3.204 & 2.758 & 19.15 & 23.21 & 24.60 & 27.26 & 23.57 \\
\hline FC5 & 14.06 & 16.39 & 16.87 & 19.70 & 16.75 & 2.815 & 3.518 & 3.581 & 4.346 & 3.564 & 24.31 & 28.75 & 29.04 & 33.19 & 28.82 \\
\hline \multicolumn{16}{|c|}{ Second Season (2017) } \\
\hline FC1 & 14.18 & 18.00 & 18.82 & 21.82 & 18.19 & 2.774 & 3.754 & 3.713 & 4.651 & 3.722 & 24.05 & 29.66 & 29.98 & 35.28 & 29.74 \\
\hline FC2 & 8.83 & 12.53 & 11.11 & 16.25 & 12.19 & 1.877 & 2.285 & 2.633 & 3.386 & 2.544 & 15.02 & 20.81 & 18.94 & 26.57 & 20.33 \\
\hline FC3 & 13.92 & 17.78 & 18.14 & 21.65 & 17.86 & 2.878 & 3.754 & 3.550 & 4.224 & 3.600 & 23.06 & 29.09 & 31.08 & 35.11 & 29.59 \\
\hline FC4 & 12.46 & 14.78 & 14.81 & 17.09 & 14.78 & 2.407 & 2.878 & 2.906 & 3.408 & 2.899 & 20.06 & 24.05 & 24.19 & 28.06 & 24.10 \\
\hline FC5 & 14.04 & 17.88 & 18.48 & 21.72 & 18.02 & 2.825 & 3.754 & 3.631 & 4.438 & 3.662 & 23.57 & 29.38 & 30.53 & 35.18 & 29.66 \\
\hline Mean & 12.70 & 16.20 & 16.27 & 19.70 & & 2.551 & 3.286 & 3.286 & 4.020 & & 21.14 & 26.59 & 26.93 & 32.04 & \\
\hline
\end{tabular}

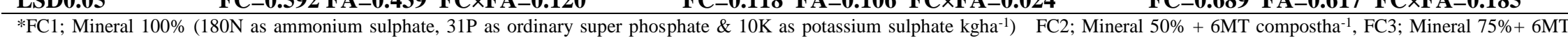
compostha ${ }^{-1}$, FC4; Mineral 50\% + 12MT compostha ${ }^{-1}$, FC5; Mineral 75\%+12MT compostha ${ }^{-1}$. 
Table 5. Effect of fulvic acid (FA) and Fertilizer combinations (FC) on Fe, Zn and Mn uptake of leaves of ofroselle plants during 2016 and 2017 seasons

\begin{tabular}{|c|c|c|c|c|c|c|c|c|c|c|c|c|c|c|c|}
\hline \multicolumn{16}{|c|}{ First Season (2016) } \\
\hline \multirow{3}{*}{$\begin{array}{c}\text { Parameters } \\
\text { FC } \\
\text { treatments* }\end{array}$} & \multirow{2}{*}{\multicolumn{4}{|c|}{$\begin{array}{c}\text { Fe uptake }\left(\mathrm{gha}^{-1}\right) \\
\text { Fulvic Acid }\left(\text { FA) in } \mathrm{mgL}^{-1}\right.\end{array}$}} & \multirow{3}{*}{ Mean } & \multirow{2}{*}{\multicolumn{4}{|c|}{$\begin{array}{c}\text { Zn uptake }\left(\text { gha }^{-1} \text {.) }\right. \\
\text { ulvic Acid (FA) in } \text { mgL }^{-1}\end{array}$}} & \multirow{3}{*}{ Mean } & \multirow{2}{*}{\multicolumn{4}{|c|}{$\frac{\text { Mn uptake }\left(\mathrm{gha}^{-1}\right)}{\text { Fulvic Acid (FA) in } \text { mgL }^{-1}}$}} & \multirow{3}{*}{ Mean } \\
\hline & & & & & & & & & & & & & & & \\
\hline & $\mathbf{0}$ & 250 & 500 & 750 & & $\mathbf{0}$ & 250 & 500 & 750 & & $\mathbf{0}$ & 250 & 500 & 750 & \\
\hline FC1 & 657.1 & 777.8 & 757.0 & 898.3 & 772.6 & 354.5 & 430.3 & 415.4 & 505.9 & 426.5 & 146.1 & 184.6 & 184.2 & 223.2 & 184.5 \\
\hline FC2 & 421.0 & 530.4 & 490.1 & 639.8 & 520.3 & 198.0 & 248.9 & 269.3 & 299.8 & 253.9 & 74.7 & 125.2 & 120.2 & 175.7 & 123.9 \\
\hline FC3 & 660.0 & 797.5 & 796.3 & 935.0 & 797.3 & 343.0 & 421.0 & 421.7 & 498.7 & 421.0 & 154.7 & 196.1 & 196.1 & 237.4 & 196.1 \\
\hline FC4 & 509.0 & 651.6 & 700.8 & 794.2 & 663.8 & 254.6 & 328.1 & 368.2 & 401.8 & 338.2 & 117.5 & 150.9 & 174.8 & 184.2 & 156.8 \\
\hline FC5 & 663.1 & 817.4 & 835.7 & 971.8 & 822.0 & 331.4 & 411.4 & 427.7 & 491.5 & 415.4 & 163.4 & 207.5 & 207.9 & 251.5 & 207.6 \\
\hline Mean & 582.0 & 715.0 & 715.9 & 847.9 & & 296.4 & 367.9 & 380.4 & 439.4 & & 131.3 & 172.8 & 176.6 & 214.4 & \\
\hline LSD0.05 & \multicolumn{3}{|c|}{$\mathrm{FC}=15.89 \quad \mathrm{FA}=14.23$} & $\mathbf{F C} \times \mathbf{F A}=$ & 4.92 & \multicolumn{5}{|c|}{$F C=9.94 \quad F A=8.88 \quad F C \times F A=2.88$} & \multicolumn{5}{|c|}{$\mathrm{FC}=6.77 \mathrm{FA}=6.05 \quad \mathrm{FC} \times \mathrm{FA}=1.56$} \\
\hline \multicolumn{16}{|c|}{ Second Season (2017) } \\
\hline FC1 & 678.5 & 785.5 & 835.7 & 993.1 & 823.2 & 395.0 & 487.7 & 475.4 & 580.1 & 484.6 & 155.7 & 196.6 & 193.8 & 237.5 & 195.9 \\
\hline FC2 & 447.4 & 593.8 & 621.6 & 796.1 & 614.6 & 192.5 & 287.5 & 270.5 & 382.6 & 283.2 & 86.7 & 112.2 & 131.2 & 137.7 & 117.0 \\
\hline FC3 & 707.0 & 846.7 & 862.3 & 1017.8 & 858.5 & 388.3 & 482.9 & 489.4 & 577.7 & 484.6 & 158.6 & 204.2 & 206.4 & 249.8 & 204.7 \\
\hline FC4 & 611.3 & 708.2 & 725.3 & 839.3 & 721.0 & 305.5 & 403.4 & 423.1 & 501.4 & 408.5 & 120.2 & 162.9 & 188.7 & 205.6 & 169.3 \\
\hline FC5 & 735.6 & 907.9 & 889.0 & 1042.6 & 893.8 & 381.6 & 478.3 & 503.3 & 575.0 & 484.6 & 161.6 & 211.8 & 218.9 & 262.2 & 213.6 \\
\hline Mean & 636.0 & 768.5 & 786.7 & 937.7 & & 332.6 & 427.9 & 432.2 & 523.4 & & 136.5 & 177.6 & 187.8 & 218.5 & \\
\hline
\end{tabular}

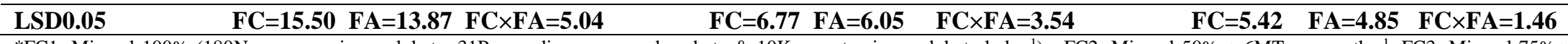

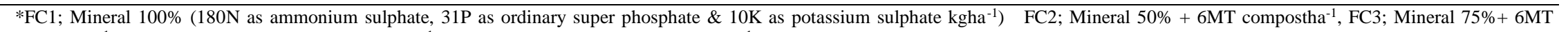
compostha $^{-1}$, FC4; Mineral 50\% + 12MT compostha ${ }^{-1}$, FC5; Mineral 75\% + 12MT compostha ${ }^{-1}$. 
Table 6. Effect of fulvic acid (FA) and Fertilizer combinations (FC) on Yield of dry sepals, seed and seed fixed oil of roselle plants during 2016 and 2017 seasons

\begin{tabular}{|c|c|c|c|c|c|c|c|c|c|c|c|c|c|c|c|}
\hline \multicolumn{16}{|c|}{ First Season (2016) } \\
\hline Parameters & \multirow{2}{*}{\multicolumn{4}{|c|}{$\begin{array}{l}\text { Dry sepals yield }\left(\mathrm{MTha}^{-1}\right) \\
\text { Fulvic Acid (FA) in moL } \\
\end{array}$}} & \multirow{3}{*}{ Mean } & & ed yiel & (MTha & & \multirow{3}{*}{ Mean } & \multirow{2}{*}{\multicolumn{4}{|c|}{$\begin{array}{l}\text { Seed fixed oil yield }\left(\mathrm{Lha}^{-1}\right) \\
\text { Fulvic Acid (FA) in } \mathrm{mgL}^{-1}\end{array}$}} & \multirow{3}{*}{ Mean } \\
\hline FC & & & & & & \multicolumn{4}{|c|}{ Fulvic Acid (FA) in $\mathrm{mgL}^{-1}$} & & & & & & \\
\hline treatments* & $\mathbf{0}$ & 250 & 500 & 750 & & $\mathbf{0}$ & 250 & 500 & 750 & & $\mathbf{0}$ & 250 & 500 & 750 & \\
\hline FC1 & 0.900 & 1.003 & 1.044 & 1.190 & 1.034 & 1.406 & 1.613 & 1.625 & 1.843 & 1.622 & 189.5 & 219.0 & 220.9 & 252.2 & 220.4 \\
\hline FC2 & 0.732 & 0.804 & 0.852 & 0.972 & 0.840 & 1.135 & 1.265 & 1.332 & 1.529 & 1.315 & 163.8 & 184.1 & 195.7 & 227.6 & 192.8 \\
\hline FC3 & 0.919 & 1.042 & 1.061 & 1.200 & 1.056 & 1.394 & 1.625 & 1.606 & 1.814 & 1.610 & 196.5 & 229.6 & 228.3 & 260.1 & 228.6 \\
\hline FC4 & 0.835 & 0.962 & 0.979 & 1.126 & 0.977 & 1.313 & 1.507 & 1.541 & 1.769 & 1.531 & 182.3 & 221.4 & 221.2 & 260.1 & 221.3 \\
\hline FC5 & 0.938 & 1.080 & 1.075 & 1.212 & 1.075 & 1.380 & 1.639 & 1.584 & 1.788 & 1.598 & 203.6 & 240.2 & 235.8 & 268.0 & 236.9 \\
\hline Mean & 0.864 & 0.979 & 1.003 & 1.140 & & 1.325 & 1.529 & 1.538 & 1.750 & & 187.2 & 218.9 & 220.4 & 253.6 & \\
\hline LSD0.05 & \multicolumn{3}{|c|}{$F C=0.010 \quad F A=0.009$} & \multicolumn{2}{|c|}{$\mathrm{FC} \times \mathrm{FA}=0.005$} & \multicolumn{5}{|c|}{$F C=0.018$ FA $=0.016$ FC $\times F A=0.007$} & \multicolumn{5}{|c|}{$\mathrm{FC}=2.820 \quad \mathrm{FA}=2.522 \mathrm{FC} \times \mathrm{FA}=0.950$} \\
\hline \multicolumn{16}{|c|}{ Second Season (2017) } \\
\hline FC1 & 1.109 & 1.169 & 1.186 & 1.262 & 1.181 & 1.601 & 1.723 & 1.805 & 1.848 & 1.745 & 211.5 & 231.9 & 240.6 & 252.2 & 234.0 \\
\hline FC2 & 0.965 & 0.962 & 0.967 & 0.967 & 0.965 & 1.450 & 1.433 & 1.507 & 1.418 & 1.452 & 204.3 & 210.1 & 218.6 & 215.9 & 212.2 \\
\hline FC3 & 1.111 & 1.210 & 1.195 & 1.279 & 1.198 & 1.613 & 1.721 & 1.778 & 1.831 & 1.735 & 226.5 & 244.5 & 254.5 & 262.5 & 247.0 \\
\hline FC4 & 0.941 & 0.994 & 1.104 & 1.265 & 1.075 & 1.452 & 1.586 & 1.555 & 1.723 & 1.579 & 216.3 & 233.6 & 238.9 & 250.9 & 234.9 \\
\hline FC5 & 1.114 & 1.253 & 1.205 & 1.294 & 1.217 & 1.625 & 1.718 & 1.752 & 1.812 & 1.728 & 241.6 & 257.2 & 268.3 & 272.8 & 260.0 \\
\hline Mean & 1.049 & 1.118 & 1.130 & 1.214 & & 1.548 & 1.637 & 1.680 & 1.726 & & 220.0 & 235.5 & 244.2 & 250.9 & \\
\hline LSD0.05 & \multicolumn{2}{|c|}{$F C=0.0386 \quad F$} & $=0.0336$ & FC $\times$ FA & 0.0043 & $\mathbf{F C}=0$ & 379 FA & 0.0341 & FC $\times$ FA & 0.0050 & \multicolumn{5}{|c|}{$\mathrm{FC}=3.288 \quad \mathrm{FA}=2.942 \quad \mathrm{FC} \times \mathrm{FA}=0.660$} \\
\hline
\end{tabular}

*FC1; Mineral 100\% (180N as ammonium sulphate, 31P as ordinary super phosphate \& 10K as potassium sulphate kgha $\left.{ }^{-1}\right) \quad$ FC2; Mineral 50\% $+6 \mathrm{MT}^{2}$ compostha ${ }^{-1}$, FC3; Mineral 75\%+ 6MT compostha $^{-1}$, FC4; Mineral 50\% + 12MT compostha ${ }^{-1}$, FC5; Mineral 75\%+12MT compostha ${ }^{-1}$. 
Table 7. Effect of fulvic acid (FA) and Fertilizer combinations (FC) on Antocyanin, Vitamin-C and Acidity of dry sepals of roselle plants during 2016 and 2017 seasons

\begin{tabular}{|c|c|c|c|c|c|c|c|c|c|c|c|c|c|c|c|}
\hline \multicolumn{16}{|c|}{ First Season (2016) } \\
\hline \multirow{3}{*}{$\begin{array}{c}\text { Parameters } \\
\text { FC } \\
\text { treatments* }\end{array}$} & \multirow{2}{*}{\multicolumn{4}{|c|}{$\begin{array}{c}\text { Sepals Anthocyanin (mg/100g DW) } \\
\text { Fulvic Acid (FA) in } \mathrm{mgL}^{-1}\end{array}$}} & \multirow{3}{*}{ Mean } & \multirow{2}{*}{\multicolumn{4}{|c|}{$\begin{array}{c}\text { Sepals Vitamin-C }(\mathrm{mg} / 100 \mathrm{~g} \text { DW) } \\
\text { Fulvic Acid (FA) in } \mathrm{mgL}^{-1}\end{array}$}} & \multirow{3}{*}{ Mean } & \multirow{2}{*}{\multicolumn{4}{|c|}{$\begin{array}{l}\text { Sepals acidity (pH value) } \\
\text { Fulvic Acid (FA) in } \text { mgL }^{-1}\end{array}$}} & \multirow{3}{*}{ Mean } \\
\hline & & & & & & & & & & & & & & & \\
\hline & $\mathbf{0}$ & 250 & 500 & 750 & & $\mathbf{0}$ & 250 & 500 & 750 & & $\mathbf{0}$ & 250 & 500 & 750 & \\
\hline FC1 & 143.1 & 146.5 & 151.6 & 149.9 & 147.7 & 34.63 & 39.13 & 40.34 & 43.63 & 39.43 & 1.989 & 2.015 & 1.938 & 1.862 & 1.951 \\
\hline FC2 & 140.4 & 142.2 & 153.7 & 144.1 & 145.1 & 35.63 & 35.35 & 37.60 & 35.07 & 35.91 & 1.981 & 1.976 & 1.936 & 1.896 & 1.947 \\
\hline FC3 & 144.8 & 148.6 & 150.0 & 152.4 & 149.0 & 35.56 & 40.66 & 39.44 & 45.76 & 40.35 & 1.972 & 1.938 & 1.934 & 1.930 & 1.943 \\
\hline FC4 & 146.6 & 150.8 & 148.4 & 155.0 & 150.2 & 37.09 & 36.98 & 45.25 & 36.86 & 39.04 & 1.853 & 2.032 & 1.955 & 1.879 & 1.930 \\
\hline FC5 & 144.6 & 151.9 & 147.9 & 159.2 & 150.9 & 36.48 & 42.18 & 38.53 & 47.88 & 41.27 & 2.049 & 1.802 & 1.823 & 1.845 & 1.880 \\
\hline Mean & 143.9 & 148.0 & 150.3 & 152.1 & & 35.88 & 38.86 & 40.23 & 41.84 & & 1.969 & 1.952 & 1.917 & 1.882 & \\
\hline LSD0.05 & \multicolumn{5}{|c|}{$\mathrm{FC}=3.191 \mathrm{FA}=2.854 \mathrm{FC} \times \mathrm{FA}=0.185$} & \multicolumn{5}{|c|}{$\mathrm{FC}=2.757 \mathrm{FA}=2.466 \mathrm{FC} \times \mathrm{FA}=0.149$} & \multicolumn{5}{|c|}{$\mathrm{FC}=0.0504 \mathrm{FA}=0.0424 \mathrm{FC} \times \mathrm{FA}=0.0023$} \\
\hline \multicolumn{16}{|c|}{ Second Season (2017) } \\
\hline FC1 & 147.2 & 150.7 & 156.5 & 154.2 & 152.2 & 36.18 & 40.32 & 39.27 & 44.46 & 40.05 & 2.066 & 2.049 & 1.968 & 1.887 & 1.992 \\
\hline FC2 & 144.0 & 146.1 & 158.4 & 148.2 & 149.2 & 35.11 & 35.32 & 36.72 & 35.53 & 35.67 & 2.006 & 1.989 & 1.934 & 1.879 & 1.952 \\
\hline FC3 & 147.8 & 152.7 & 154.1 & 157.7 & 153.1 & 36.07 & 41.59 & 39.25 & 47.10 & 41.00 & 2.019 & 1.955 & 1.921 & 1.887 & 1.945 \\
\hline FC4 & 146.5 & 155.0 & 145.8 & 163.5 & 152.7 & 37.24 & 36.70 & 47.71 & 36.16 & 39.45 & 1.964 & 1.853 & 1.845 & 1.836 & 1.874 \\
\hline FC5 & 148.3 & 154.7 & 151.6 & 161.1 & 153.9 & 35.97 & 42.86 & 39.24 & 49.75 & 41.95 & 2.032 & 1.921 & 1.908 & 1.896 & 1.939 \\
\hline Mean & 146.8 & 151.8 & 153.3 & 156.9 & & 36.11 & 39.36 & 40.44 & 42.60 & & 2.017 & 1.953 & 1.915 & 1.877 & \\
\hline
\end{tabular}

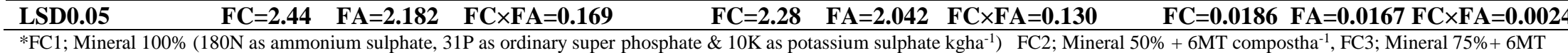

compostha $^{-1}$, FC4; Mineral 50\% + 12MT compostha ${ }^{-1}$, FC5; Mineral 75\%+ 12MT compostha ${ }^{-1}$ 
seed fixed oil (268.0 and $\left.272.8 \mathrm{Lha}^{-1}\right)$ in the $1^{\text {st }}$ and $2^{\text {nd }}$ season, respectively.

The previous results of fertilization with respect to yield parameters are in parallel with those obtained by El-khayat (2001) on roselle plants, Niakan et al. (2004) on Mentha piperita, El-Maadawy and Moursy (2007) on jojoba, El-Shora (2009) on Mentha piperita, Khalil et al. (2010) on basil plants, Majeed and Ali (2011) on roselle plant, Gendy et al. (2012) on roselle plants, Gendy et al. (2013) on guar plants, Priya et al (2014) on tobacco plant, Paramasivan et al. (2015) on Solanum melongena L., Khatab (2016) on roselle plant and Moradi et al (2017) on safflower plant.

\section{Sepals quality parameters:}

\subsection{Sepals anthocyanin content:}

Table 7 showed that the highest anthocyanin content ( $180.79 \mathrm{mg} / 100 \mathrm{~g} \mathrm{DW}$ ) was accumulated in sepals as a result of using FC5 treatment ( 150.9 and $153.9 \mathrm{mg} / 100 \mathrm{~g}$ DW) in the $1^{\text {st }}$ and $2^{\text {nd }}$ seasons, respectively. No significant differences were observed between FC5, FC1, FC3 and FC4 in both seasons. In addition, FA foliar application at $750 \mathrm{mg} / \mathrm{L}$ was the highest significant $(152.1$ and $156.9 \mathrm{mg} / 100 \mathrm{~g}$ DW) and no significant differences between this treatment and FA at $500 \mathrm{mg} / \mathrm{L}$ one treatment in the $1^{\text {st }}$ and $2^{\text {nd }}$ season, respectively. In general, the interaction effect of FC5 and FC4 with foliar application of fulvic acid at 750 resulted in the highest anthocyanin content of roselle sepals i.e. 159.2 and $163.5 \mathrm{mg} / 100 \mathrm{~g} \mathrm{DW}$ in the $1^{\text {st }}$ and $2^{\text {nd }}$ seasons, respectively.

\subsection{Sepals vitamin $C$ content:}

Data in Table 7 indicate that the highest content of vitamin C (41.27 and $41.95 \mathrm{mg} / 100 \mathrm{~g}$ DW) was noticed at FC5 in the $1^{\text {st }}$ and $2^{\text {nd }}$ seasons, respectively, and no significant differences was observed among FC1, FC3, FC4 and FC5 in both study seasons. Moreover, foliar application of fulvic acid (FA) significantly increased sepals content of vitamin C compared to no FA application in both study seasons. On the other hand, the interaction of FC5 with FA at $750 \mathrm{mg} / \mathrm{L}$ showed to be the most effective one for enhancing the highest sepals vitamin-C content $(47.88$ and $49.75 \mathrm{mg} / 100 \mathrm{~g} \mathrm{DW}$, in the $1^{\text {st }}$ and $2^{\text {nd }}$ seasons, respectively).

\subsection{Sepals acidity value:}

Data in Table 7 show that the highest significant sepals acidity value was noticed at FC1 treatment (1.951 and 1.992) in the $1^{\text {st }}$ and $2^{\text {nd }}$ seasons, respectively, while the lowest sepals acidity value was due to FC5 treatment whish had no significant differences with FC1, FC3 and FC4 treatments in both study seasons. Regarding the effect of fulvic acid treatments, no application of FA treatment achieved the highest acidity values (1.969 and
2.017 ) in the $1^{\text {st }}$ and $2^{\text {nd }}$ seasons, respectively, whereas FA at 750 showed the lowest sepals acidty value and no significant differences among FA application treatments i.e. FA at 750,500 and $250 \mathrm{mg} / \mathrm{L}$ in both study seasons. Generally, slightly reducing in sepals acidity values were scored due to the interaction between FC5 with all FA foliar application treatments i.e. FA at 750,500 and $250 \mathrm{mg} / \mathrm{L}$ in both study seasons.

The previous data of sepals quality parameters (i.e. sepals anthocyanin, vitamin $\mathrm{C}$ and acidity) in close conformity with the findings of El-khayat (2001) on roselle plants, Niakan et al. (2004) on Mentha piperita, El-Maadawy and Moursy (2007) on jojoba, El-Shora (2009) on Mentha piperita, Khalil et al. (2010) on basil plants, Majeed and Ali (2011) on roselle plant, Gendy et al. (2012) on roselle plants, Gendy et al. (2013) on guar plants, Priya et al. (2014) on tobacco plant, Paramasivan et al. (2015) on Solanum melongena L., Khatab (2016) on roselle plant and Moradi et al (2017) on safflower plant.

\section{Net profit and net return:}

To recognize the net profit and net return of the different studied treatments, the average increase of dry sepals yield $\left(\mathrm{MTha}^{-1}\right)$ as a main yield of roselle plant, were calculated during both study seasons by comparing the lowest sepals dry yield at FC2+FA0 treatment with the that at the other treatments (Table, 8).

Results indicated that the highest net profit $\left(40.450 \times 10^{3}\right.$ LEha $\left.^{-1}\right)$ and the highest net return $\left(29.336 \times 10^{3} \mathrm{LEha}^{-1}\right)$ were achieved due to the dual application of FC5 with FA at $750 \mathrm{mgL}^{-1}$.

\section{CONCLUSION}

Fulvic acids (FAs) are a mixture of weak aliphatic and aromatic organic acids which are soluble in water at all $\mathrm{pH}$ conditions (acidic, neutral and alkaline). Their composition and shape is quite variable. The size of fulvic acids (HFs) are smaller than humic adds (HAs), with molecular weights which range from approximately 1,000 to 10,000 . Fulvic acids (FAs) have an oxygen content twice that of humic acids (HAs). They have many carboxyl $(\mathrm{COOH})$ and hydroxyl $(\mathrm{COH})$ groups, thus fulvic acids (FAs) are much more chemically reactive. The exchange capacity of fulvic acids (FAs) is more than double that of humic acids (HAs). This high exchange capacity is due to the total number of carboxyl $(\mathrm{COOH})$ groups present. The number of carboxyl groups present in fulvic acids (FAs) ranges from 520 to $1120 \mathrm{cmol}(\mathrm{H}+) / \mathrm{kg}$. Fulvic acids collected from many different sources and analyzed, show no evidence of methoxy groups $\left(\mathrm{CH}_{3}\right)$ groups, they are low in phenols, and are less aromatic compared to humic acids from the same sources. Because of the relatively small size of 
Table 8. Net profit and net return for the average increase in dry sepals yield for both study seasons

\begin{tabular}{lccccc}
\hline Treatments & $\begin{array}{c}\text { Average } \\
\text { yield } \\
\text { MT/fed }\end{array}$ & $\begin{array}{c}\text { Average } \\
\text { Increase } \\
\text { in yield } \\
\text { MTha }^{-1}\end{array}$ & $\begin{array}{c}\text { Cost } \\
\mathbf{L E} \times \mathbf{1 0}^{\mathbf{3}} \\
\mathbf{h a}^{-\mathbf{1}}\end{array}$ & $\begin{array}{c}\text { Net } \\
\text { profit } \\
\mathbf{L E} \times \mathbf{1 0}^{\mathbf{3}} \\
\text { ha }^{-\mathbf{1}}\end{array}$ & $\begin{array}{c}\text { Net } \\
\text { return } \\
\text { LE } \times \mathbf{1 0}^{\mathbf{3}} \\
\mathbf{h a}^{-\mathbf{1}}\end{array}$ \\
\hline FC1+FA0 & 1.005 & 0.156 & 6.419 & 15.600 & 9.181 \\
FC2+FA0 & 0.849 & 0.000 & 5.010 & 0.000 & -5.010 \\
FC3+FA0 & 1.015 & 0.167 & 6.614 & 16.650 & 10.036 \\
FC4+FA0 & 0.888 & 0.039 & 6.810 & 3.950 & -2.860 \\
FC5+FA0 & 1.026 & 0.178 & 8.414 & 17.750 & 9.336 \\
FC1+FA250 & 1.086 & 0.238 & 7.319 & 23.750 & 16.431 \\
FC2+FA250 & 0.883 & 0.035 & 5.910 & 3.450 & -2.460 \\
FC3+FA250 & 1.126 & 0.278 & 7.514 & 27.750 & 20.236 \\
FC4+FA250 & 0.978 & 0.130 & 7.710 & 12.950 & 5.241 \\
FC5+FA250 & 1.167 & 0.318 & 9.314 & 31.800 & 22.486 \\
FC1+FA500 & 1.115 & 0.267 & 8.219 & 26.650 & 18.431 \\
FC2+FA500 & 0.910 & 0.061 & 6.810 & 6.100 & -0.710 \\
FC3+FA500 & 1.128 & 0.280 & 8.414 & 27.950 & 19.536 \\
FC4+FA500 & 1.042 & 0.193 & 8.610 & 19.300 & 10.691 \\
FC5+FA500 & 1.140 & 0.292 & 10.214 & 29.150 & 18.936 \\
FC1+FA750 & 1.226 & 0.378 & 9.119 & 37.750 & 28.631 \\
FC2+FA750 & 0.970 & 0.121 & 7.710 & 12.100 & 4.391 \\
FC3+FA750 & 1.240 & 0.391 & 9.784 & 39.100 & 29.316 \\
FC4+FA750 & 1.196 & 0.347 & 9.510 & 34.700 & 25.191 \\
FC5+FA750 & 1.253 & 0.405 & 11.114 & 40.450 & 29.336 \\
\hline
\end{tabular}

FC1; Mineral 100\% (180N as ammonium sulphate, 31P as ordinary super phosphate \& 10K as potassium sulphate kgha $\left.{ }^{-1}\right) \quad \mathrm{FC}^{2}$; Mineral $50 \%+$ $6 \mathrm{MT}$ compostha $^{-1}$, FC3; Mineral 75\% + 6MT compostha ${ }^{-1}$, FC4; Mineral 50\% + 12MT compostha ${ }^{-1}$, FC5; Mineral 75\%+ 12MT compostha ${ }^{-1}$.

fulvic acid (FA) molecules they can readily enter plant roots, stems, and leaves. As they enter these plant parts they carry nutrients from plant surfaces into plant tissues. Foliar spray applications containing fulvic acid (FA) mineral chelates, at specific plant growth stages, can be used as a primary production technique for maximizing the plants productive capacity. Fulvic acids (FAs) are the most effective carbon containing chelating compounds known. They are plant compatible, thus nontoxic, when applied at relatively low concentrations (Majeed and Ali (2011); Priya et al., 2014; Paramasivan et al., 2015; Khatab (2016) and Moradi et al., 2017).

To interpret and evaluate the effect of nitrogen, phosphorus and potassium concerned in this study, on augmenting the different tested vegetative growth parameters, yield component leaf nutrients content and sepals quality parameters of roselle plants, it is important to refer to the physiological roles of nitrogen, phosphorus and potassium in plant growth and development. Such three macronutrient elements are the common elements usually included in fertilizers (Cooke, 1982). Plant supplement with these macronutrients in form of fertilizers is necessary because the soil is usually in deficient of them due to plant removal leaching or they are not readily available for plants. Therefore, such addition of well balanced NPK fertilization quantities insured production of high productivity and chemical constituents of roselle plants.

Nitrogen is essential for plant growth and development as a constituent of many amino acids, enzymes and energy transfer materials such as chlorophyll, ADP and ATP. Growing plants must have nitrogen to form new cells and the rate of growth then becomes very nearly proportional to the rate at which nitrogen is supplied (Bidwell, 1974). Besides, supplying the plants with adequate quantities of $\mathrm{N}$ at right time tends to increase cell number and cell size with an overall increase in the vegetative growth production (Thompsond and Troch, 1975).

Phosphorus is essential for cell division and for development of meristematic tissues and it is very important for carbohydrate transformation due to multitude of phosphorylation reaction and to energy rich phosphate bond (Lambers et al., 2000). Phosphorus compounds are also essential for photosynthesis, the inter conversion of carbohydrates and related glycolysis, 
amino acid metabolism, fat metabolism and biological oxidation. Lack of phosphorus, therefore hampers metabolic processes, such as the conversion of sugars into starch and cellulose (Devlin, 1972).

Potassium is important for growth and elongation probably due to its function as an osmotic and may react synergistically with IAA. Moreover, it promotes $\mathrm{CO}_{2}$ assimilation and translocation of carbohydrates from the leaves to storage tissues (Mengel and Kirkby, 1987).

When organic manures added as fertilizer, it led to decrease soil $\mathrm{pH}$ which in turn increasing solubility of nutrients for plant uptake, in some cases organic materials may act as low release fertilizer. Recently, on the way of sustainable agriculture with minimum effects, the use of organic manures as natural soil amendments is recommended to replace the soluble chemical fertilizers. They improve the structure of weak-structured sandy soils and increase their water holding capacity. Also, they improve soil fertility, and stimulate root development, induce active biological conditions and enhancing activities of micro-organisms especially those involved in mineralization (Zheljazkov and Warman, 2004).

The present study, therefore, indicated that the using the integration between mineral (NPK) and organic fertilizers (compost and fulvic acid) has become an urgent necessity to provide maximum net return and high exportation characteristics for medicinal plants such as roselle plant due to its important roles in reducing soil and water pollution consequently playing a safety role on human health especially under Siwa Oasis conditions as a natural reserve.

\section{REFERENCES}

A.O.A.C. 1980. Official Methods of Analysis, $12^{\text {th }}$ Ed. Association of official analysis chemists :Washington. D.C. U.S.A.

Aggag, A. M., A. M.Alzoheiry and A. E. Abdallah.2015. Effect of kaolin and fulvic acid antitranspirants on tomato plants grown under different water regimes. Alex. Sci. Exch. J. 36 (2): 169-179.

Amran, K.A.A. 2013. Physiological studies on Pelargonium graveolens L plant. Ph.D. Thesis, Fac. of Agric., Moshtohor, Benha. Univ.

Anjum, S. A., L.Wang, M. Farooq, L. Xue and S. Ali. 2011. Fulvic acid application improves the maize performance under well-watered and drought conditions. Journal of Agro. Crop Sci. 197 (6):409- 417.

Ashorabadi, E.S., A. Matin and M.H. Lebaschi. 2003. Investigate of physiological growth indices in fennel (Foeniculum vulgare). Iranian, Journal of Medicinal and Aromatic Plants Research. 19 (2): 157-182.
Black, C.A., D.O. Evans, L.E. Ensminger, J.L. White, F.E. Clark and R.C. Dinauer. 1982. Methods of Soil Analysis. part 2. Chemical and microbiological properties. 2nd Ed. Soil Sci.,Soc. of Am. Inc. Publ. Madison, Wisconsin, U. S.A.

Bocanegra, M. P., J. C. Lobartini and G. A. Orioli. 2006. Plant uptake of iron chelated by humic acids of different molecular weights. Communications Soil Sci. Plant Anal. 37: $1-2$.

Brown, J.D. and O. Lilleland. 1946. Rapid determination of potassium and sodium in plant material and soil extract by flame photometry. Proc. Amer. Soc. Hort. Sci. 48:341-346.

Chapman, H.D. and P.F. Paratt. 1961. Methods of Soil, Plants and Water Analysis. Univ. California, Div. Agric. Sci.314p.

Devlin, R.M. 1972. "Plant Physiology". Third Edition. Van Nostrand Company, New YorK, N.Y.

Diab, M.A. 1968. The chemical composition of Hibiscus sabdariffa, L. M.Sc. Thesis, Fac. of Agric. Cairo Univ.

Du, C.T. and F. J. Francis. 1973. Anthocyanins of roselle. Amherst, Mass. J. Food. Sci. 38(5): 310-312.

Eid, Rawia, A., S. Lobna Taha and M.M. Soad Ibrahiem. 2011. Alleviation of adverse effect of salinity on growth and chemical constituents of marigold plants by using glutathione and ascorbiate. J. Appli. Sci. Res. 7(5): 714721.

El-khayat, A.S.M. 2001. Physiological effects of tryptophane, thiamin and ascorbic acid on Hibiscus sabdariffa, L. plant. The Fifth Arabian Horticulture Conference, Ismailia, Egypt, March 24-28. Vol. II. P: 251-264.

El-Khyat, L.A.S. 2013. Effect of chemical and bio fertilizer on growth and chemical composition of rosemary plants. M.Sc. Thesis Fac. Agric. Moshtohor, Benha Univ.

El-Maadawy, E.I. and Kh.S. Moursy.2007. Bio-fertilizers as a partial alternative to chemical NPKL fertilization of jojoba (Simmondsia chinensis, L.) plants grown in different soil types. J. Product. \& Dev. 12 (1): 211-236.

El-Shora, S.E.E. 2009. Physiological studies on Mentha Spp. (fertilization - post harvest treatments). M.Sc. Thesis, Fac. Of Agric. Benha Univ.

El-Shrief M.H. and M.I. Sarwat. 2007. Physiological and chemical variation in producing Roselle plant by using some organic farmyard manure. World J. Agric. Sci. .3(5):609-616.

FAO Soil Bulletin .1977. China recycling of organic wastes in agriculture. FAO Soil Bull. 40 Rome.

Farag, M.F.M. 2009. The effect of some amino acids and antioxidants on morphological, anatomical characters, chemical constituents and yeild of canola plant (Brassica napus L.). Ph.D Thesis Fac. Agric. Fayom Univ.

Fasoyiro, S.B., O.A.A. Adeola and F.O. Samuel. 2005. Chemical and storability of fruit flavoured (Hibiscus sabdariffa) drinks. World J. Agric. Sci. 1: 165-168. 
Gendy, A.S.H., H.A.H. Said-Al Ahl and Abeer A. Mahmoud. 2012. Growth, productivity and chemical constituents of roselle (Hibiscus sabdariffa L.) plants as influenced by cattle manure and biofertilizers treatments. Australian J. Basic Applied Sci.6(5): 1-12.

Gendy, A.S.H., H.A.H. Said-Al Ahl, A. A. Mahmoud and H. F. Y. Mohamed.2013. Effect of nitrogen sourses, biofertilizers and their interaction on the growth, seed yield and chemical composition of guar plants. Life Sci. J. 10(3): 389-402.

Gomaa, A.O. and A.S.M. Youssef.2007. Influence of chemical, organic and bio-fertilizer application on growth and productivity of lovage plant (Levisticum officinale, koch). Egypt J. of Appl. Sci. 22 (IIB): 492-520.

Hendawy, S. F., M. S. Hussein, A. E. El-Gohary and M. E. Ibrahim. 2015. Effect of foliar organic fertilization on the growth, yield and oil content of Mentha piperita var.citrata. Asian J. Agric. Res. 9 (5): 237-248.

Herbert, D., P.J. Phipps, and R.E. Strange. 1971. Determination of total carbohydrates, Methods in Microbiology. 5 (8): 290-344.

Hilbert H., Soyer J.P., Molot C., Giraudon J., Milin S. and Gaudillere J.P.(2003). Effects of nitrogen supply on must quality and anthocyanin accumulation in berries of cv. Merlot. Vitis 42 (2), 69-76.

Hussin, M.S., S.E. El-Sherbeny, H.M. El-Saeid and M.M. Kandeel. 1991. Field experiments of foliar application with B-9 and Micronutrients on Hibiscus sabdariffa, L. (1) Growth yield and hormonal content. J. Egypt Hort Vol. 16 (1): 59- 68.

Jackson, M.L. 1973. Soil Chemical Analysis. Prentice-Hall of Indian Private, New Delhi.

Jifon, J. L. and Lester, G. E. 2009. Foliar potassium fertilization improves fruit quality of field-grown muskmelon on calcareous soils in south Texas. J. Sci. Food Agric. 89, 2452-2460.

Kamel, S. M., M. M. I.Afifi, F. El-shoraky and M. M. ElSawy. 2014. Fulvic acid: a tool for controlling powdery and downy mildews in cucumber plants. Inter. J. Phytopathology, 3 (2):101-108.

Kandeel, Y.M.R. 2004. Effect of bio, organic and chemical fertilization on growth, essential oil productivity and chemical composition of Ocimum basilicum, L. plant. Annals of Agric. Sci., Moshtohor, Vol. 42 (3): 1253-1270.

Khalil, Soha, E., N. G. Abd El-Aziz, and B.H. Abou Leil. 2010. Effect of water stress and ascorbic acid on some morphological and biochemical composition of Ocimum basilicum plant. J.Am. Sci. 6(12): 33-44.

Khatab, A. Kh. 2016.Response of Roselle Plants (Hibiscus sabdariffa L.) to Pressed Olive Cake Compost Types and Potassium Fertilization Rates on Newly Reclaimed Soils at Siwa Oasis, Egypt. J. Soil Sci. and Agric. Eng., Mansoura Univ., Vol. 7 (5): 365 - 373.

Kulikova, N.A., E.V. Stepanova, and O.V. Koroleva. 2005. Mitigating activity of humic substances: Direct influence on biota. In: Use of humic substances to remediate polluted environments: From theory to practice (Ed.: I.U. Perminova). NATO Science Series IV. Earth and Environmental Series. Kluwer Academic Publishers: 285309.

Lambers, H., F.S. Chapin and T.L. pons. 2000. Plant physiology Ecology. Springer - verleg New Yourk.Inc.

Lee, K., M. Yang, Supanjani and D.L. Smith. 2005. Fertilizer effect on the yield and terpene components from the flower heads of Chrysanthemum boreale, $\mathrm{M}$. (Compositae). Agro. Sustainable Develop.25 (2): 205-211.

Li, M.S., S. Li and B. L. C. Zhang. 2005. Physiological effect of new FA antitranspirant on winter wheat at ear filling stage. J. Agric. Sci. China. 11:820-825.

Majeed K. A. and A.S. Ali. 2011. Effect of foliar application of NPK on some growth characters of two cultivars of Roselle (Hibiscus sabdariffa L.). Am. J. Plant Physiol., 6(4):220-227.

Mengel, K. and A. Kirkby. 1987. Principles of Plant Nutrition $4^{\text {th }}$ Ed. International. Potash, Institute. Bern. Switzerland.

Moradi , P. , B. Pasari and F. Fayyaz.2017. The effects of fulvic acid application on seed and oil yield of safflower cultivars. J. Central European Agric. 18(3): 584-597.

Nardi, S., D. Pizzeghello, A. Muscolo and A. Vianello. 2002. Physiological effects of humic substances on higher plants. Soil Biology \& Biochemistry. 34:1527-1536.

Niakan, M., R.A. Khavarynejad and M.B. Rezaee. 2004. Effects of different rates of NPK fertilizer on the leaf fresh weight, dry weight, leaf area and oil content of Mentha piperita, L. Iranian J. Medicinal and Aromatic Plants Res. 20 (2): 131-148.

Paramasivan, M. V. Arukumar and T. Prabhu. 2015. Effect of humic acid and inorganic fertilizers on productivity, profitability, nutrient uptake and soil fertility in brinjal (Solanum melongena L.) var. KKM1 in Alfisol of Tamil Nadu. Asian J. Soil Sci.,10(2):185-190.

Priya, B. N. V., K. Mahavishnan, D. S.Gurumurthy, H. Bindumadhava, A. P. Upadhyaya and N.K. Sharmaa. 2014. Fulvic Acid (FA) for enhanced nutrient uptake and growth: Insights from biochemical and genomic studies. J. Crop Improvement. 28. 6: 740-757.

Rosed, H. 1957. Modified ninhydrin colorimetric analysis for acid nitrogen. Arch. Biochem. Biophys. 67 :10-15.

Schmidt, W., S. Cesco, S.Santi, R. Pinton and Z. Varanini. 2005. Water-extractable humic substances as nutrient acquisition signals for root hairs development in Arabidopsis. In: Hartmann, A., Schmid, M., Wenzel, W., Hinnsinger, P. 2004.Rizosphere-Perspectives and Challenges:1171-1178.Elsevier.

Sharaf, A. 1962. The pharmacological characteristics of Hibiscus sabdariffa, L. (N.Res Centre Dokki Cairo) Planta Med 10:48-52.

Shehata S.A., A.A. Gharib, M. Mohamed, K.F. El-Mogy Abdel Gawad and E. A.S halaby. 2011. Influence of compost, amino and humic acids on the growth, and yield and chemical parameters of strawberries. J. Medicinal Plants Res. 5(11).pp: 2304-2308. 
Silva, R. D. A., J. L. Santos, L. S. Oliveira, M. R. S. Soares and S. M. S. D. Santos. 2016. Biostimulants on mineral nutrition and fiber quality of cotton crop. Revista Brasileira de Engenharia Agrícola e Ambiental. 20 (12): 1062-1066.

Snedecor, G.W. and W.G. Cochran.1989. Statistical methods. $8^{\text {th }}$ Ed., Iowa State Univ., Press, Iowa ,U.S.A.

Suh, H. Y., K. S. Yoo and S. G. Suh. 2014. Effect of foliar application of fulvic acid on plant growth and fruit quality of tomato (Lycopersicon esculentum L.). Horticulture, Environ. Biotechnol. 55 (6):455-461.

Thomas, W. and R.A. Dutcher. 1924. The colorimetric determination of carbohydrates methods. J. Amr. Chem. Soc. 46:1662-1669.

Thompsond, L.M. and F.R. Troch. 1975. Soils and Soil Fertility. TATA Mc- Graw- Hill pub. Co. Ltd. New Delhi.

Trouge, E. and A.H. Meyer. 1939. Improvement in deiness calorimetric for phosphorus and arsenic. Ind. Eng. Chem. Anal. Ed. 1: 136-139.

Türkmen, O., A. Dursun, M. Turan and C. Erdinc. 2004. Calcium and humic acid affect seed germination, growth and nutrient content of tomato (Lycopersicon esculentum L.) seedlings under saline soil conditions. Acta Horticul. Scandinavica B. 54: 168-174.
Xudan, X. 1987. The effect of foliar application of fulvic acid on water use, nutrient uptake and yield in wheat. Australian J. Agric. Res. 37: 343-350.

Yamauchi, M., S. Katayama, T. Todoroki and T.Watanable. 1984. Total synthesis of fulvic acid. J. Chemical Soc., Chemical Communications. 23:1565-1576.

Yang, C.M., M.H. Wang, Y.F. Lu, I.F. Chang, and C.H. Chou. 2013.Humic substances affect the activity of chlorophyllase. Chem. Ecol. J. 30: 1057-1065.

Yazdani, B., A. Nikbakht and N. A. Etemadi. 2014.Physiological effects of different combinations of humic and fulvic acid on gerbera. Communications Soil Sci. Plant Analysis. 45:1357-1368.

Zahra, M. K., M. Monib, Sh. I. Abbdel-Al and A. Heggo. 1984. Significance of soil inoculation with silicate bacteria. Zentralblatt fur Mikrobiologie.139: 349-357.

Zancani, M., A. Bertolini, E. Petrussa, J. Krajňájivá and A. Piccolo. 2011. Fulvic acid affects proliferation and maturation phases in Abies cephalonica embryogenic cells. J. Plant Physiol. 168:1226-1233.

Zheljazkov, V.D. and P.R.Warman. 2004. Source-Separated Municipal Solid Waste Compost Application to Swiss Chard and Basil. J. Environ. Qual. 33: 542-552. 


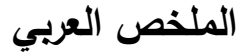

\section{تأثير التسميد العضوى والمعدنى مع الرش بحامض الفالفيك على إمتصاص المغذيات وجودة وإنتاجية نبات الكركدية النامى فى واحة سيوة، مصر فئر \\ محرم فؤاد عطيه}

أثنارت النتائج إلى أن المعاملة FC5 منفردة والمعاملة

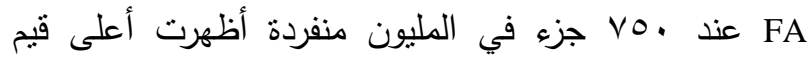
معنوية لارتفاع النبات (سم) ، عدد الأوراق / النبات ، الوزن التردي

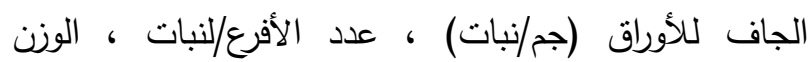

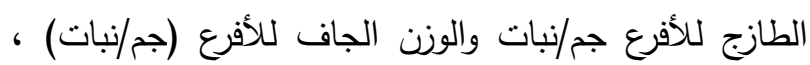
المنص من العناصر الكبرى والصغرى فى الأوراق النيات ومحصول كل من السبلات والبذور (طن/هكتار) ومحصول الإن

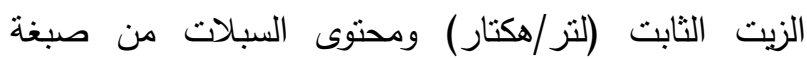

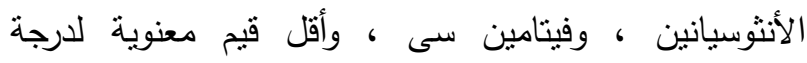
الحموضة بالسبلات فى كلا موسمى الدراسة وقد أدت الإضافة المزدوجة للمعاملة FC5 مع المعاملة عند . FA

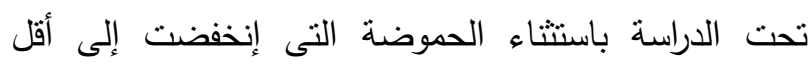
درجاتها فى كلا موسمى الدراسة. فعلى ذلك يوصى باهئ باستخدام

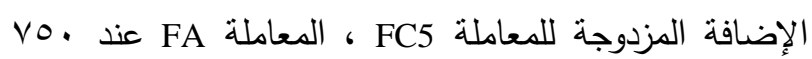

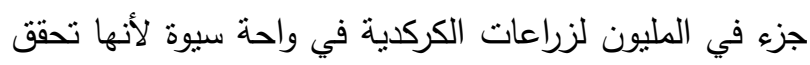

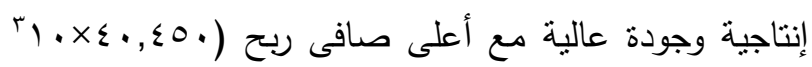

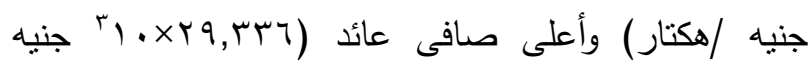
/هكتار)ولأن بها إستبدال جزئى للأسمدة المعدنية بالأسمدة

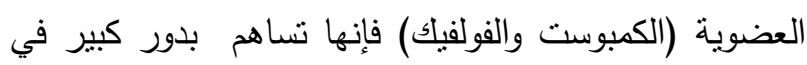
الحد من تلوث التربة ومياه الرى خاصة تحت ظروف واحة

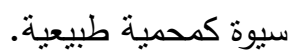

أجريت تجربة حقلية خلال موسمين متعاقبين (7 ( ب ، ،

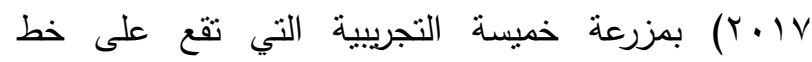

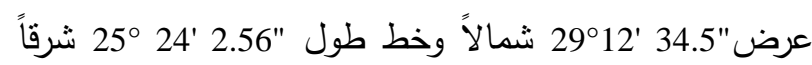
بمحطة بحوث سيوة ، محافظة مطروح ، مركز بحوث

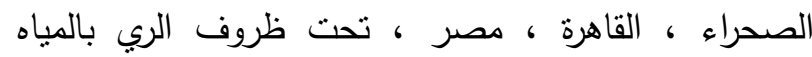

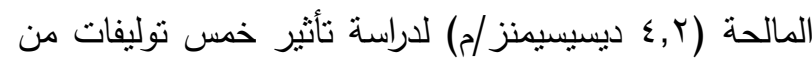

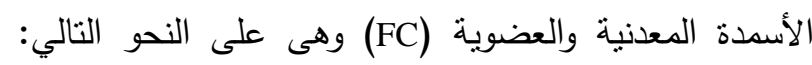

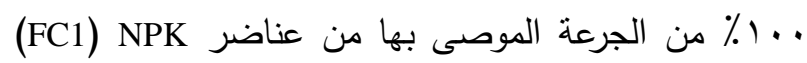

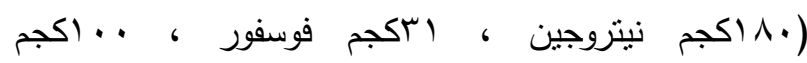

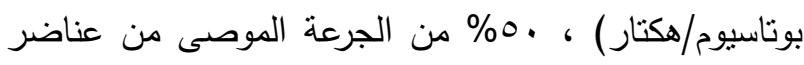

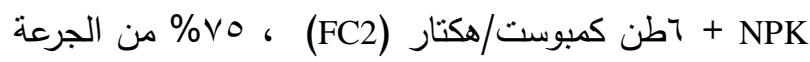
الموصى من عناضر NPK + اطن كمبوست/هكتار (FC3)

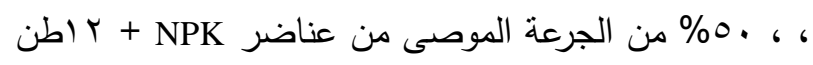

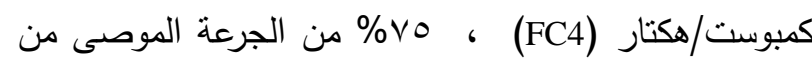

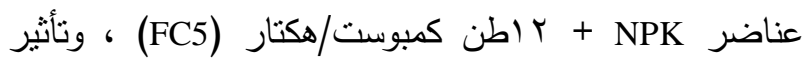

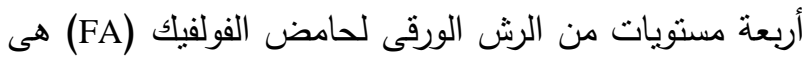

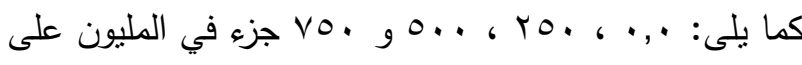
كل من مقاييس النمو الخضري ، امتصاص المغذيات الورقية ، وجودة وإنتاجية محصول نبات الكركديه ، وقد نفذت التجربة

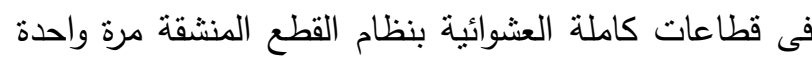

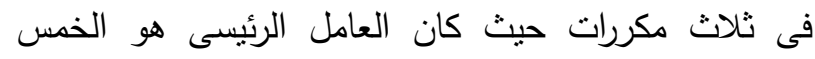

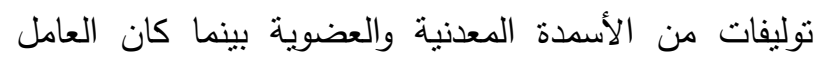
تحت الرئيسى هو مستويات الرش الورقى حامض الفولفيك. 